\title{
Component-Resolved Diagnostics: Shedding Light on the So-Called 'Squishy Science' of Food Allergies?
}

\author{
Jennifer S. Kim Anna Nowak-Węgrzyn \\ Division of Allergy and Immunology, Department of Pediatrics, Jaffe Food Allergy Institute, Mount Sinai School of \\ Medicine, New York, N.Y., USA
}

Recently, the editors of the New York Times invited knowledgeable outside contributors to discuss the systematic review of the available evidence on the prevalence, diagnosis, management, and prevention of food allergies published in the Journal of the American Medical Association in 2010 [1]. They entitled their blog 'The Squishy Science of Food Allergies' [2], and it was a discussion triggered by the commissioned federal report which found that a uniform definition of what a food allergy is or how to test for one was lacking. There were few highquality studies. The New York Times title may somewhat belittle the complexities of the diagnosis of food allergies but also conveys the difficulties inherent in our less-thanperfect testing modalities available for food allergy.

Modern society favors instant and definitive outcomes, primarily because technology has allowed for such. However, immediate conclusions cannot always be reasonably delivered in medicine and particularly in food allergy. Certainly, the diagnostic value of our current testing modalities via the blood and skin are limited by the relatively low positive predictive value (PPV) and are overly sensitive in detecting relevant specific IgE anti- body. Component-resolved diagnostics (CRD) has been introduced recently as a promising tool to assess specific IgE antibodies against multiple recombinant or purified natural allergen components. CRD has been widely utilized for research purposes with the application of protein as well as peptide microarray chip technology. One of the advantages of the chip technology is the ability to obtain a wealth of information from a minute amount of blood, which is particularly helpful in infants and young children. CRD provides significant insights into the process of sensitization by defining the primary sensitizers, cross-reactivity patterns, and potential markers of systemic reactions in plant food allergy.

This issue's article by Moverare et al. [3] evaluates 74 Swedish subjects with known peanut sensitization and a history of suspected peanut allergy. Within this cohort, $65 \%$ of subjects had specific IgE antibodies to Ara h 1, 2, or 3 whereas $35 \%$ had no detectable IgE antibodies to these recombinant peanut storage proteins. Among the group positive to Ara h 1-3, 60\% of subjects had peanutspecific IgE levels $>15 \mathrm{kU}_{\mathrm{A}} / \mathrm{l}$ (median $21 \mathrm{kU}_{\mathrm{A}} / \mathrm{l}$ ) whereas all subjects in the group negative to Ara h 1-3 had peanut-

\section{KARGER}

Fax +41613061234 E-Mail karger@karger.ch www.karger.com
(C) 2011 S. Karger AG, Basel

$1018-2438 / 11 / 1563-0231 \$ 38.00 / 0$

Accessible online at:

www.karger.com/iaa
Correspondence to: Dr. Anna Nowak-Wegrzyn

Division of Allergy and Immunology, Department of Pediatrics

Jaffe Food Allergy Institute, Mount Sinai School of Medicine

5 East 98th Street, 10th floor, New York, NY 10029 (USA)

Tel. +1 212241 5548, E-Mail anna.nowak-wegrzyn@mssm.edu 
specific IgE levels $<10 \mathrm{kU}_{\mathrm{A}} / \mathrm{l}$ (median $0.73 \mathrm{kU}_{\mathrm{A}} / \mathrm{l}$ ); the difference was statistically significant. Based on questionnaire data, self-reported symptoms were also evaluated. Fifty-eight subjects $(78 \%)$ reported a previous adverse reaction after peanut ingestion. However, no confirmatory oral challenges were performed. Respiratory distress (asthma or dyspnea) was reported by 26 subjects (45\%), a significantly higher proportion of which were in the group positive for Ara h 1-3 (56 vs. 18\% in the group negative for Ara h 1-3). Thus, the authors concluded that the presence of IgE sensitization to Ara h 1,2, or 3 was associated with severe peanut reactions within their cohort. The authors acknowledge that further research using oral food challenges is warranted to confirm their findings.

Oral food challenges were used in a few prior studies to evaluate the clinical applications of CRD in food allergy. Nicolaou et al. [4] used microarray CRD to determine if clinical peanut allergy could be differentiated from peanut sensitization. Within a population-based cohort, peanut sensitization was ascertained at age 8 years. Oral challenges were then performed to establish the clinical diagnosis of peanut allergy, except in subjects having a convincing history of reaction plus $>95 \%$ PPV for peanut-specific $\operatorname{IgE}\left(\geq 15 \mathrm{kU}_{\mathrm{A}} / \mathrm{l}\right.$ or skin test $\left.\geq 8 \mathrm{~mm}\right)$. The prevalence of peanut sensitization was $12 \%$ within this population. Among those sensitized, 22\% were diagnosed with clinical peanut allergy. Sensitization profiles were compared between peanut-reactive $(n=29)$ and peanut-tolerant children $(\mathrm{n}=52)$ by using microarray with 12 components. Subjects with peanut allergy had higher 'fold-change values' (calculated expression level estimates of the sample against the negative controls) to major peanut components Ara h 1-3 whereas the peanuttolerant subjects had higher values to cross-reactive carbohydrate determinants and grass components ( $\mathrm{Phl} \mathrm{p} \mathrm{1,}$ 4 , and $5 \mathrm{~b}$ ). The groups did not differ for Ara h 8 or Bet $\mathrm{v}$ 1. The misclassification rate was $17.5 \%$ when using peanut-specific $\operatorname{IgE} \geq 15 \mathrm{kU}_{\mathrm{A}} / \mathrm{l}$ and $15 \%$ with use of a skin prick test meal wheal diameter $\geq 8 \mathrm{~mm}$. The misclassification rate (and what that cutoff would be) using only Ara h 2, deemed the most important predictor of clinical allergy, was not reported but a model was developed using all 12 components simultaneously, producing a misclassification rate of $7.4 \%$.

Ando et al. [5] evaluated the utility of ovomucoid-specific IgE antibodies (ImmunoCAP, Phadia) to predict tolerance to heated egg. Subjects with suspected egg allergy ( $\mathrm{n}=108)$ underwent double-blind placebo-controlled challenges to raw and heated egg (at $90^{\circ} \mathrm{C}$ or $194^{\circ} \mathrm{F}$ for 60 $\min )$. While specific IgE to egg white $\left(>7 \mathrm{kU} \mathrm{A}_{\mathrm{A}} / \mathrm{l}\right)$ was most useful in the diagnosis of allergy to raw egg white, ovomucoid-specific $\operatorname{IgE}\left(>11 \mathrm{kU}_{\mathrm{A}} / \mathrm{l}\right)$ was superior in predicting reactions to heated egg white.

Ott et al. [6] analyzed 145 oral challenges serving as reference parameters for CRD using microarray technology for suspected allergy to cow's milk $(\mathrm{n}=85)$ and hen's eggs $(n=60)$. CRD was not shown to be capable of replacing oral food challenges, and testing with singular allergen components did not prove to be superior to in vitro testing for whole antigen (UniCAP; Phadia, Uppsala, Sweden). The authors suggest the use of microarrayed allergen components as a low-invasive tool because of the low amount of serum required for analysis; blood can be derived via capillaries instead of via peripheral venipuncture. However, diagnostic capability was not enhanced with use of CRD in this study.

Validation of CRD accuracy must occur with use of oral food challenges, the gold standard for diagnosing food allergy as affirmed by guidelines published in December 2010 by the NIAID-sponsored expert panel [7]. Similarly, the World Allergy Organization Clinical Guidelines on cow's milk allergy (DRACMA) [8] did not find a diagnostic advantage for CRD in a GRADE methodology review of studies of cow's milk allergen-specific IgE antibody measurement using microarrays $[9,10]$ and suggested that CRD should be used only in a research context [10]. However, CRD may help refine indications for oral challenges and encourage oral challenges in borderline situations such as when long-term avoidance has been instituted based on positive test results ( $>95 \%$ PPV) without a history of clinical reaction.

In conclusion, CRD may indeed prove to shed light on the 'squishy science' [2] of food allergy by providing more precise clinical immunologic data, but further evidence is necessary to define its applicability. It is unlikely that CRD will replace the current gold standard for food allergy diagnosis - an oral food challenge.

References

1 Chafen JJ, Newberry SJ, Riedl MA, Bravata DM, Maglione M, Suttorp MJ, Sundaram V, Paige NM, Towfigh A, Hulley BJ, Shekelle PG: Diagnosing and managing common food allergies: a systematic review. JAMA 2010;303:1848-1856.

2 The New York Times: The Squishy Science of Food Allergies. 2010. http://roomfordebate. blogs.nytimes.com/2010/05/16/the-squishyscience-of-food-allergies/?ref=research (accessed January 7, 2011). 
3 Movérare R, Ahlstedt S, Bengtsson U, Borres MP, van Hage M, Poorafshar M, Sjölander S, Åkerström J, van Odijk J: Evaluation of IgE antibodies to recombinant peanut allergens in patients with reported reactions to peanut. Int Arch Allergy Immunol 2011;156: 282-290.

-4 Nicolaou N, Poorafshar M, Murray C, et al: Allergy or tolerance in children sensitized to peanut: prevalence and differentiation using component-resolved diagnostics. J Allergy Clin Immunol 2010;125:191-197.
Ando H, Moverare R, Kondo Y, et al: Utility of ovomucoid-specific IgE concentrations in predicting symptomatic egg allergy. J Allergy Clin Immunol 2008;122:583-588.

6 Ott H, Baron JM, Heise R, et al: Clinical usefulness of microarray-based IgE detection in children with suspected food allergy. Allergy 2008;63:1521-1528

7 Boyce JA, Assa'ad A, Burks AW, et al: Guidelines for the diagnosis and management of food allergy in the United States: report of the NIAID-sponsored expert panel. J Allergy Clin Immunol 2010;126:S1-S58.

8 Fiocchi A, Brozek J, Schünemann $\mathrm{H}$, et al: World Allergy Organization (WAO) Diagnosis and Rationale for Action against Cow's Milk Allergy (DRACMA) Guidelines. Pediatr Allergy Immunol 2010;21:1-125.
$>9$ Gaudin JC, Rabesona H, Choiset Y, et al: Assessment of the immunoglobulin E-mediated immune response to milk-specific proteins in allergic patients using microarrays. Clin Exp Allergy 2008;38:686-693.

10 Noh G, Ahn HS, Cho NY, Lee S, Oh JW: The clinical significance of food specific IgE/ IgG4 in food specific atopic dermatitis. Pediatr Allergy Immunol 2007;18:63-70. 